\title{
Halokinetics and other features of GLORIA long-range sidescan sonar data from the Red Sea
}

DOI:

10.1016/j.marpetgeo.2017.09.017

\section{Document Version}

Accepted author manuscript

Link to publication record in Manchester Research Explorer

\section{Citation for published version (APA):}

Mitchell, N., \& Augustin, N. (2017). Halokinetics and other features of GLORIA long-range sidescan sonar data from the Red Sea. Marine and Petroleum Geology, 88, 724-738. https://doi.org/10.1016/j.marpetgeo.2017.09.017

\section{Published in:}

Marine and Petroleum Geology

\section{Citing this paper}

Please note that where the full-text provided on Manchester Research Explorer is the Author Accepted Manuscript or Proof version this may differ from the final Published version. If citing, it is advised that you check and use the publisher's definitive version.

\section{General rights}

Copyright and moral rights for the publications made accessible in the Research Explorer are retained by the authors and/or other copyright owners and it is a condition of accessing publications that users recognise and abide by the legal requirements associated with these rights.

\section{Takedown policy}

If you believe that this document breaches copyright please refer to the University of Manchester's Takedown Procedures [http://man.ac.uk/04Y6Bo] or contact uml.scholarlycommunications@manchester.ac.uk providing relevant details, so we can investigate your claim.

\section{OPEN ACCESS}




\section{Halokinetics and other features of GLORIA long-range}

\section{2 sidescan sonar data from the Red Sea}

3

$4 \quad$ Neil C. Mitchell ${ }^{1}$ and Nico Augustin ${ }^{2}$

5

6 'School of Earth and Environmental Sciences, University of Manchester, Williamson

7 Building, Oxford Road, Manchester M13 9PL, UK.

8

$9 \quad{ }^{2}$ GEOMAR Helmholtz Centre for Ocean Research Kiel, Wischhofstr. 1-3, 24148 Kiel, 10 Germany

12 For correspondence: neil.mitchell at manchester.ac.uk

15 Keywords: halokinetic deformation, salt flows, salt glaciers, sidescan sonar, 16 multibeam sonar.

20 Abstract

21 The Red Sea is an unusual example of a rift basin that transitioned from its

22 evaporitic stage to fully open-ocean conditions at the end of the Miocene $(\sim 5.3$

$23 \mathrm{Ma}$ ), much more recently than older Mesozoic margins around the Atlantic and

24 Gulf of Mexico. The patterns of halokinetic deformation occurring in the Red Sea 
25 are potentially of interest for understanding more generally how evaporite

26 deposits deform during this early stage. Relevant to this issue, a line of

27 reconnaissance sidescan sonar data (GLORIA) collected along the Red Sea in

281979 is re-evaluated here. We first interpret the data with the aid of newly

29 compiled bathymetry from multibeam sonars in the central and southern Red

30 Sea. Features in the acoustic backscatter data are associated with ridges, valleys

31 and rounded flow fronts produced by halokinetic deformation. Some areas of

32 higher acoustic backscattering from the evaporites are suggested to relate to

33 roughness produced by deformation of the evaporite surface. Within the

34 volcanic (oceanic) axial valleys, areas of differing high and low backscattering

35 suggest varied sediment cover and/or carbonate encrustations. With the benefit

36 of the above experience, we then interpreted data from the northern Red Sea,

37 where there are fewer multibeam data available. Rounded fronts of halokinetic

38 deformation are present in the Zabargad Fracture Zone, a broad, shallow valley

39 crossing the Red Sea obliquely. The presence of halokinetic deformation here is

40 evidence that subsidence has occurred along the fracture zone. Elsewhere in the

41 northern Red Sea, the GLORIA data reveal folds in the evaporite surface,

42 suggesting local areas of convergence, like those implied by multibeam data from

43 inter-trough zones further south. Some linear features are observed, many of

44 which are likely to be ridges overlying salt walls. Interestingly, several such

45 features are oriented along an accommodation zone that is oriented parallel to

46 the plate spreading direction. Several rounded, corrugated features are

47 interpreted as possible evaporite flow fronts. Overall, the impression from the

48 data is of a strongly mobile seabed in the Red Sea because of halokinetic

49 deformation, involving both vertical and horizontal movements. However, salt 
50

51

52

53

54

55

56

57

58

59

60

61

62

63

64

65

66

67

68

69

70

71

72

73

74

walls appear more common than in the central and southern axial Red Sea,

where horizontal movements instead tend to dominate.

Introduction

The Red Sea is an unusual example of rifted continent transitioning to ocean basin, with evaporites deposited up until the end of the Miocene deformed in a range of halokinetic structures as a result of the axial rifting and differential subsidence (Augustin et al., 2014; Augustin et al., 2016; Bicknell et al., 1986; Bonatti et al., 1984; Ehrhardt and Hübscher, 2015; Ehrhardt et al., 2005; Feldens and Mitchell, 2015; Girdler and Whitmarsh, 1974; Ligi et al., 2012; Ligi et al., 2011; Mitchell et al., 2010a; Mitchell et al., 2017; Rowan, 2014; Searle and Ross, 1975). Although the precise geometrical and temporal details have yet to be worked out, the Red Sea may suggest how the evaporites now forming thick but mobilised deposits around Atlantic and Gulf of Mexico basins deformed during the early stages of margin development in those areas (Bonatti et al., 1970; Pautot et al., 1966; Rona, 1982).

The Geological LOng Range Inclined Asdic (GLORIA) was a low-frequency (6.5 kHz) sidescan sonar developed in the 1960s and 1970s for reconnaissance mapping of the seabed (Rusby et al., 1969; Rusby, 1970; Somers et al., 1978; Somers and Searle, 1984). During RRS Discovery cruise 103, the system was run along a zigzag track traversing the length of the Red Sea (Figure 1; Searle (1980)). Garfunkel et al. (1987) reported results of the survey covering the central and southern Red Sea, although they only showed GLORIA data with automatic gain control (AGC). AGC is high-pass filtering intended to highlight faults and other abrupt structures. We present the full dataset here without AGC 
75 (though with time-varied gain compensating for spreading and attenuation

76 losses), as variations in grey levels can help to reveal, for example, the extent of

77 surface muddy sediment and rock outcrops. The GLORIA data are first compared

78 with recently published bathymetry data collected with multibeam sonars

79 (Augustin et al., 2014; Augustin et al., 2016; Mitchell et al., 2010a). The

80 comparison shows how finer-scale features in the GLORIA images correspond

81 with seabed structure. We then use that experience to guide interpretation of

82 previously unpublished GLORIA data from the northern Red Sea, which reveal

83 widespread halokinetic deformation, though with structures suggesting a

84 different emphasis of vertical and horizontal movements.

85

86

87

88

89

90

91

92

93

94

95

96

97

98

99

\section{Background to morphology and halokinetic deformation of the Red Sea}

In the southern Red Sea south of $\sim 20^{\circ} \mathrm{N}$, continuous magnetic anomalies and volcanic geomorphology suggest that an axial spreading centre is continuously exposed (Cochran, 1983; Augustin et al., 2014, 2016). In the free-air gravity field (lower-left inset to Figure 1), anomalies are subdued suggesting that the shortwavelength basement rugosity is also subdued. If the evaporites were deposited until the end of the Miocene with a continuous, horizontal surface throughout the Red Sea, the exposure of the spreading axis in the south is potentially explained simply by the higher elevation of the ridge axis near to the Afar mantle plume (Mitchell et al., 2017).

The central Red Sea ("Transitional region" in Figure 1) contains closedcontour depressions ("deeps") floored with volcanic geomorphological features in multibeam data. Those deeps are separated by elevated inter-trough zones (ITZs), which seismic reflection data suggest contain evaporites (Bonatti et al., 
100

101

102

103

104

105

106

107

108

109

110

111

112

113 et al., 2010; Augustin et al., 2014, 2016; Feldens and Mitchell, 2015). Figure 2 124 shows a 3D view of a segment of the data overlooking Erba Deep. Salt flows such

1984). Magnetic anomalies outside the deeps are somewhat lineated but are subdued and their shapes in profile cannot be identified as seafloor spreading anomalies (Izzeldin, 1987), leading some authors to consider the deeps as new oceanic spreading centres and areas around them as highly extended continental crust (Bonatti et al., 1984; Ligi et al., 2011, 2012). Improved resolution of the free-air gravity field obtained from satellite altimetry (Sandwell et al., 2014) has prompted another interpretation. The field shows many linear features crossing the central Red Sea in directions subparallel with the plate spreading direction ("FZs" in lower-left inset to Figure 1). These are similar morphologically in gravity data to short-offset fracture zones or other discontinuities of slow-spreading mid-ocean ridge spreading centres, suggesting that the central Red Sea is floored by oceanic crust (Mitchell and Park, 2014). If correct, magnetic anomalies may be attenuated as a consequence of greater depth of the crust associated with the loading by the evaporites, which reach several $\mathrm{km}$ in thickness away from the axis in seismic data (Izzeldin, 1987; Tramontini and Davis, 1969; Egloff et al., 1991). Other explanations include overlapping lava flows leaving distributed magnetization directions (Labrecque and Zitellini, 1985), hydrothermal alteration (Levi and Riddihough, 1986; Augustin et al., 2014) or lack of a well-defined extrusive layer (Dyment et al., 2013). extensive pattern of glacier-like features, folds and faults that have been attributed to flowage of the Miocene evaporites in the central Red Sea (Mitchell 
125 as those shown have rounded fronts in plan-view and profile, with longitudinal

126 ridges and valleys much like ice glaciers (flow fronts can in detail have

127 undulations or steps, which we show later produce curved repeated features in

128 GLORIA images). The rift valley is floored with cones and irregular ridges typical

129 of volcanic oceanic spreading centres. The ITZs are sites where flowage has been

130 extensive, completely filling the axial valley (such as at the main flow in Figure

131 2), whereas the evaporites appear to be held back by obstructions in other areas,

132 leaving the axial valley exposed. One obvious obstruction occurs immediately

133 north of the largest flow in Figure 2, with lineaments in the evaporites wrapping

134 around it as a result of the flowage.

135 Seismic basement in these areas generally dips away from the axis or is

136 flat when corrected for seismic velocity (Egloff et al., 1991; Izzeldin, 1987;

137 Tramontini and Davies, 1969). Some of the seismic data show a higher basement

138 on either side of the axial valley (Izzeldin, 1987), much like the crestal mountains

139 of a normal (un-sedimented) slow-spreading mid-ocean ridge. Local relief of the

140 basement is also suggested by maps of Bouguer gravity anomalies (e.g., Mitchell

141 et al., 2017). They show the above-mentioned fracture zone valleys lining up

142 with the ITZs. As the evaporite surface and the seabed are also commonly

143 depressed over the fracture zones, flowage appears to be preferentially

144 exploiting gaps in the crestal mountains along the fracture zone valleys

145 (Augustin et al., 2014; Mitchell et al., 2017). This inference suggests a link

146 between basement structure and the pattern of flowage in the central Red Sea.

147 Less is known of the pattern of flowage in the northern Red Sea. The

148 seabed generally dips towards the centre of the basin (Figure 1), suggesting that

149 evaporites tend to flow towards the axis. As in the central Red Sea, the 
evaporites can reach several $\mathrm{km}$ in thickness, although unlike the central Red Sea the underlying basement in places dip towards the rift axis (upper-left inset to Figure 1). Based on the various geophysical and geological data in the literature, almost the entire northern Red Sea is covered by evaporites so the features we observe below are mostly underlain by evaporites. Shallow seismic reflection data from the far northern Red Sea near Sinai have revealed salt walls overlying basement faults oriented NW-SE (Mart and Rabinowitz, 1986; Mart and Ross, 1987). Salt walls have similarly been found at Conrad and other deeps (Ehrhardt et al., 2005; Ehrhardt and Hübscher, 2015). Industry seismic reflection data suggest the existence of salt walls parallel to the Saudi Arabian coast (Richter et al., 1991) and similar structures exist on the opposing Egyptian side (Gordon et al., 2010). One segment of seismic reflection data from the Saudi Arabian margin (Rowan, 2014) shows a giant recumbent isoclinal fold in the evaporites produced by flowage towards the rift axis. However, the data publically available has been too limited to map out the directions of flowage and any relationships between that flowage and basement structure have been unclear.

\section{Dataset and interpretation method}

Data quality

According to the cruise report (Searle, 1980), the data were collected with the Mark II GLORIA system (Somers et al., 1978) with a $400 \mathrm{~m}$ tow cable during RRS Discovery cruise 103. The pulse repetition frequency was $40 \mathrm{~s}$, so the maximum range achieved was $30 \mathrm{~km}$, i.e., a maximum potential swath width of $60 \mathrm{~km}$. Refraction effects mentioned below and strong attenuation in the Red Sea, where salinity can exceed 40 ppt., and shallow depths often led to around half the 
maximum width in practice being imaged. The data recorded against acoustic travel time were converted by the shipboard engineers to slant range from the sonar vehicle using the known speed of sound in water and echo-sounder data. (As the data were not projected to ground range, features are geometrically distorted within the first few km of ship tracks.) A photographic film was then exposed with those results, with scan rate derived from navigation data to ensure common along and cross-track distance scales. The film was then developed and printed. We have digitally scanned the prints and assembled mosaics of the data along ship tracks as shown in Figures 3 to 7 . Images were scaled and oriented so that the hourly tick marks shown down the centre of each swath matched the hourly marks along the ship tracks. (some images are offset from tracks to avoid overlaps).

The track for Discovery 103 obtained from the National Geophysical Data Center (NGDC; www.ngdc.noaa.gov) unfortunately contains some errors (Figure 1) that are not present in the track plot of the original cruise report (Searle, 1980). East of Mabahiss Deep, the provided track overlaps land. A sharp left jog of the track northwest of Vema Deep and a right jog east of Hatiba Deep are not associated with any indications of a sharp change of course in the GLORIA images (course changes would normally result in a loss of signal as the reception beam moved away from the transition beam during turns). As marked in Figure 1 , no transit satellite fixes were recorded between $24^{\circ}$ and $26^{\circ} \mathrm{N}$, so navigation between these points was only by dead reckoning. We have positioned the GLORIA images ignoring the first jog mentioned, while the segment of imagery east of Mabahiss Mons seamount was positioned continuing the trend of the track running further north. Features in the data were also matched as closely as 
200

201

202

203

204

205

206

\section{GLORIA data interpretation} 224 influences outlined below, but is effective if the interpreter bears these issues in

possible to slopes in the multibeam bathymetry map of Guennoc et al. (1990) and with the linear feature marked "F" in Figure 6 constrained to lie seaward of land. The locations and geometries of features should be interpreted bearing in mind these potential navigational issues and the distribution of satellite fixes, although the data in the central and southern Red Sea appear mostly to correspond well with the newer multibeam data (Augustin et al., 2014; Augustin et al., 2016), which are shown in Figures 3 and 4.

Complicating the interpretation of the GLORIA images, ray-tracing calculations demonstrate that refraction of the signal in the water column can cause convergence of the signal towards the far range from the vehicle and limit the swath width (Mitchell and Somers, 1989; Searle et al., 1990). Although we have not carried out such calculations for the Red Sea survey, the GLORIA data show irregular bands of highly backscattered signal in the far range, running parallel to track (e.g., in the northerly swaths shown in Figures 4 and 5). In parts of the data from the northern Red Sea where this is a problem (Figure 7), segments of the far range parts of the data has been cut out to prevent them distracting readers. In another artefact, high backscatter from escarpments can appear more extended than the originating feature would suggest. For example, the two volcanic ridges in Thetis Deep (Figure 4) appear broader in the GLORIA data than in the multibeam data. This may be caused by one or more reflections from the sea surface extending the duration of high backscatter.

Interpretation of sidescan sonar data can be difficult given the range of 
mind. Many complications are predictable and can be allowed for. High backscattering data are shown white and low backscattering black in these figures. When a half swath of data are viewed with the ship track higher up the page, the data appear as though a shaded relief map of the seabed, with a resolution of $\sim 100 \mathrm{~m}$ across track. High backscattering is generally produced by a seabed that is rough at scales similar to the acoustic wavelength of the sonar (23 $\mathrm{cm}$ at $6.5 \mathrm{kHz}$ here) and where there is a large acoustic impedance contrast at the seabed (Clay and Medwin, 1977). These conditions are often met by outcropping bedrock, in contrast with flat muddy sediments of smaller impedance contrast. The angle of incidence of the signal with the seabed also modulates the backscatter, so that the returned signal is greater at smaller angle of incidence (Mitchell and Somers, 1989). Backscatter modulated in this way can give an impression of seabed relief ("shape from shading"; Blondel and Murton, 1997). Also, given this incidence angle effect, the sonar tends preferentially to reveal surfaces such as fault scarps that are facing towards the sonar beam, conversely features parallel to the beam are not emphasized (though can be revealed if there is bedrock exposed along them). Because of the low frequency used with this sonar, the signal can penetrate a few metres into mud and the features may lie partly buried rather than at the seabed exactly (Mitchell, 1993). Whereas mid-grey tone in the imagery likely indicates an unconsolidated sedimentary seabed, black areas occurring behind bright areas can be caused by acoustic shadows cast by high-standing terrain (Mitchell, 1991), helping the interpreter identify areas of relief. Dredging of seabed areas in the Red Sea that have extremely low backscattering in multibeam acoustic data by one of us (NA) has recovered porous carbonate encrusted sediment, so such material (likely 
250 deposited during the Last Glacial Maximum (Almogi-Labin et al., 1998; Milliman et al., 1969)) probably occurs in many of the areas of low GLORIA backscattering, overlain by a $\sim 1 \mathrm{~m}$ drape of Holocene sediment (Mitchell et al., 2015).

We interpreted the data in the central and southern Red Sea first with the aid of the new multibeam sonar data. In the northern Red Sea, we have interpreted lineaments (both bright and dark) and backscatter boundaries mostly independently of multibeam data collected in the area since some navigational accuracy is questionable and the multibeam data are generally not available in digital form. Nevertheless, a number of published maps of multibeam data and knowledge gained from them along with seismic reflection data (Cochran et al., 1986; Coutelle et al., 1991; Ehrhardt and Hübscher, 2015; Ehrhardt et al., 2005; Guennoc et al., 1988; Guennoc et al., 1990; Mart and Ross, 1987; Martinez and Cochran, 1988) are available to confirm the nature of structures. We also created a bathymetry map for the area around Mabahiss Mons, a seamount in the northern Red Sea, by combining multibeam data of RV Pelagia from the Augustin et al. (2016) compilation with digital multibeam data of RV Jean Charcot from Guennoc et al. (1990). That map is shown in Figure 8. The features interpreted from the GLORIA data were then plotted over maps of the bathymetry (Figure 9) and free-air gravity anomalies (Figure 10), which allow the sonar features to be assessed in terms of factors likely to have affected evaporite movement (e.g., seabed gradient or basement topography, the latter reflected in the gravity field (Cochran and Karner, 2007; Mitchell and Park, 2014)). The lineaments were also plotted over a map of depth to the Miocene evaporite surface in Figure 11, which was derived from limited shallowpenetration seismic reflection data as described in Mitchell et al. (2017). Those 
data were interpolated or extrapolated from ship tracks by $0.15^{\circ}$ in latitude and

276 longitude. Hence the map represents only general variations in the evaporite

277 topography, whereas fine-scale variations due to the above-mentioned salt walls

278 and diapirs are not visible.

Observations

281 Interpretation with multibeam data from the central and southern Red Sea

282 Interpreting the GLORIA data alongside multibeam data gives us knowledge of

283 which features are likely to be imaged when we later interpret the northern Red

284 Sea GLORIA data. However, the GLORIA data also extend our knowledge of

285 structures beyond the areas covered by multibeam data in the central and

286 southern Red Sea and provide additional seabed textural information.

Just north of $18^{\circ} \mathrm{N}$ in the far south of the area studied (Figure 3), the axial

288 valley floor is marked by high backscatter ("HBVF"; please see key in figure for

289 acronyms), though with apparently flat terraces in the multibeam data producing

290 intermediate backscatter ("LBVF") presumably because of extensive sediment

291 cover. Within the valley floor, cones identifiable in the multibeam data can also

292 be observed in the GLORIA data ("v"), in places with collapse pits in their

293 summits. In some areas, the fine structure of the faults corresponds well, for

294 example, where marked by an asterisk ("*") in Figure 3 (in the multibeam data,

295 these faults each have 200-400 m of relief). The GLORIA data extend the

296 knowledge of faults beyond the multibeam data as previously outlined

297 (Garfunkel et al., 1987).

298 Evaporite flow fronts appear in the multibeam data rounded in plan-view

299 and in profile, with generally smooth sedimentary surfaces (Figure 2; Augustin et 
al., 2014; Augustin et al., 2016; Feldens and Mitchell, 2015; Mitchell et al.,

301 2010a). Flow fronts underlie the GLORIA vehicle track at the course change in

302 the southeast of Figure 3 (so are not visible there in the GLORIA data from there

303 exactly), but three flow fronts $\sim 30 \mathrm{~km}$ across can be clearly observed in both the

304 multibeam and GLORIA data to the NW of the turn. Flow fronts are commonly

305 more highly backscattering than the sediment away from the deeps, probably

306 because of small faults associated with extension in these areas or because less

307 fine grained sediment deposits on the steeper slopes. Also, shortly after the

308 course change, corrugated textures ("c") can be observed between the evaporite

309 flows. In the swath of multibeam data crossing these structures, these areas

310 contain small folds that are arcuate in plan-view (also marked "c"), where they

311 have $\sim 10-50$ m of relief. Such structures have been interpreted as where parts

312 of the flowing evaporites have become pinned or impeded by elevated

313 underlying basement features such as seamounts (Mitchell et al., 2010a; Figure

314 2). The evaporite flow front on the east side of Suakin Deep has $>1000 \mathrm{~m}$ of

315 vertical relief in the multibeam data. In the GLORIA data, a number of

316 lineaments on the flow front appear to correspond in the multibeam data with

317 small undulations of the flow front topography of a few hundred metres. In

318 contrast, an orthogonal downslope-oriented ridge and valley topography (slope

319 failures?) is not visible in the GLORIA data due to the tendency to image features

320 preferentially running parallel with the vehicle, not perpendicular.

321 Similar features are observable in the GLORIA data further north shown

322 in Figure 4. However, whereas the evaporite surface away from the flow fronts

323 is generally low backscattering, southeast of Atlantis II Deep there is an easterly

324 oriented band of high backscattering from the surface of the evaporites ("HE"). 
325 We suspect that this backscattering was caused by faults and folds within the

326 evaporite carapace, as observed around Thetis Deep (Mitchell et al., 2010a), and

327 that they have produced facets facing the sonar and greater seabed roughness.

328 The evaporite-filled depression within the inter-trough zone (ITZ) immediately

329 north of Atlantis II Deep is also visible in the GLORIA swath collected running

330 east to west (marked "c"). Folds are visible in the southerly side of this swath.

331 They have reliefs of 50-150 $\mathrm{m}$ in the multibeam data and have been interpreted

332 as the halokinetic convergence front (Augustin et al., 2014; Augustin et al., 2016).

333 The low backscattering within the north basin of Thetis Deep corresponds

334 with areas where sediments have been sampled by coring (Mitchell et al., 2010b;

335 Pierret et al., 2010). Generally, the undulations in the evaporite surface

336 modulate the GLORIA data backscattering because of the incidence angle effect.

337 The irregular rounded texture in the GLORIA data to the southeast of Erba Deep,

338 for example, can be seen corresponding with surface undulations in the

339 multibeam data. Similarly, the linear slopes running NW-SE northwest of the

340 northern basin of Thetis Deep that have been suggested to represent flowage

341 over rift valley wall faults (Mitchell et al., 2010a) appear as broad parallel bands

342 in the GLORIA imagery (in the multibeam data, these slopes have reliefs of $\sim 100$ -

$343300 \mathrm{~m}$ over $5 \mathrm{~km}$ ). The steep walls of Nereus Deep cast deep acoustic shadows

344 so little internal structure is observed in the GLORIA image there.

346 Halokinetic and other features of the data in the northern Red Sea

347 The data from the northern Red Sea (Figures 5-7) contain many of the features

348 described in the central and southern Red Sea (Figures 3-4), though largely

349 without axial volcanic and tectonic features, as the seabed is almost fully covered 
350 with evaporites and other sediments. Without the assistance of multibeam data, 351 evaporite flow fronts and other features are more difficult to interpret from the 352 data but we nevertheless propose likely examples.

353 Figure 5 reveals several areas of corrugated seabed, some of which are 354 rounded in plan-view, much like the evaporite flow fronts in Figure 3. Flow 355 directions of the interpreted evaporite flows next to Vema and Bannock deeps 356 (eff1 and eff2) are difficult to ascertain from these images alone as both convex 357 to northeast and concave to northeast corrugations occur (in Figures 9-11, we 358 show preferred SW-directed flow as more compatible with the bathymetry 359 gradients, though the bathymetry database is not based on continuous echo360 sounder data). The Zabargad Fracture Zone comprises a broad though shallow 361 trough running north-northeast of Zabargad Island. We feel more confident of 362 the flow directions for eff3 to eff6 shown in Figure 5, in part because they would 363 be compatible with gradients in the S reflection depths (Figure 11). Flows eff7 364 and eff8 were interpreted from the multibeam data in Figure 8. Flows eff9 to 365 eff11 are more speculative. Some sharp boundaries between high and moderate backscatter suggest 367 changes of gradient from steep slope to sediment-filled basin (e.g., the boundary 368 marked in Figure 6 "Base of slope" running irregularly parallel to track on both 369 sides of the sonar). Some of these may be the bases of fronts of evaporite 370 flowage. Some long (10-20 km) curvilinear features with smoothly varying 371 backscatter are marked as "evaporite folds" in Figure 6 because they appear 372 similar to the folds in the ITZ immediately north of Atlantis II Deep (Figure 4).

373 They are oriented NNE, roughly parallel with the trend of the Red Sea axis.

374 These features overlie a salt dome interpreted from industry seismic reflection 
375 data (Richter et al., 1991). Features of similar appearance, though smaller (5-10

$376 \mathrm{~km}$ ) and oriented E-W are observable NE of Oceanographer Deep (Figure 7,

377 immediately east of eff10).

378 In the northern Red Sea, lineaments with both sharp and gradual

379 backscatter variations can be observed, suggesting a variety of faults and folds, of

380 varied orientations. Other longer, broader and straighter bands of high

381 backscattering are suggested to be larger faults. For example, one marked "F" in

382 Figure 6 is oriented NNW and is shown controlling the coastline. In this case, a

383 fine crenelation of the high backscatter zone suggests that this slope contains

384 many small-scale gullies from mass-wasting. Another linear feature in the west

385 of Figure 5 at $24^{\circ} \mathrm{N}$ ("F") is oriented N015 $\mathrm{E}$. Although this part of the data was

386 affected by the vessel positioning issues mentioned earlier, the vessel was most

387 likely steered with a constant bearing (no deviations are shown in the cruise

388 report (Searle, 1980)), so these directions are probably correct to within $\sim 10^{\circ}$.

389 As mentioned by Searle et al. (1980), the GLORIA data do not reveal much

390 evidence for the Aqaba Fault (continuation of the Dead Sea Fault), although

391 lineaments with the fault orientation are shown in Figure 7 where the fault has

392 been located from seismic reflection data (Mart and Ross, 1987).

394 Discussion

395 Nature of flowage in the northern Red Sea

396 We concentrate discussion on the northern Red Sea, as the pattern of flowage is

397 already well known in the central and southern Red Sea (Augustin et al., 2014,

398 2016). Whereas we anticipate the evaporites to form diapirs where they are

399 loaded by thick terrigenous sediment near the coasts, as have been imaged with 
seismic reflection methods (Richter et al., 1991; Gordon et al., 2010), away from

401 those areas the nature of halokinesis is less clear. Rowan (2014) reported a

402 high-quality section through 3D seismic data from near the Saudi Arabian coast,

403 which shows a nappe produced by large-scale flowage seaward from the Arabian

404 margin involving many kilometres of movement. On the other hand, Mart and

405 Ross (1987) used an irregular grid of seismic reflection data to map out

406 elongated diapirs of evaporites for $\sim 100 \mathrm{~km}$ south of Sinai in the more central

407 area, trending NNW over underlying largely inactive basement faults.

408 In the northern $200 \mathrm{~km}$ of the Red Sea, we observe some structures

409 oriented NNW, parallel to the structures of Mart and Ross (1987), e.g., the

410 lineaments immediately to NW and NE of Conrad Deep. Hence, some or most of

411 these may be the seabed ridges overlying salt walls. Conrad Deep itself is

412 oriented more NNE-SSW with salt walls imaged in seismic reflection data

413 (Ehrhardt and Hübscher, 2015; Ehrhardt et al., 2005); a NNE-trending feature

414 can be observed in the GLORIA data immediately SE of the deep marked in

415 Figure 7 ("Conrad Deep fault?"). Some other linear features are more ambiguous

416 in origin. For example, the lineament marked "F" next to Oceanographer Deep

417 (Figure 7) could be a fault or the top of a salt wall. This feature is remarkably

418 long (18 km) and lines up with the underlying accommodation zone in basement

419 revealed by the gravity field (Figure 10). Other linear features can also be

420 observed further northeast aligned with the accommodation zone. The maps of

421 lineaments (Figures 9 and 10) show many other orientations of structures. The

422 data also show rounded features that could be interpreted as flow fronts, such as

423 eff10 in Figure 7, hence suggesting lateral movements. 
If significant gravity-driven movement of the evaporites has occurred, it

425 would be expected to have been oriented roughly perpendicular to the

426 bathymetry contours in Figure 9 (i.e., to the NE on the African side and to the SW

427 on the Arabian side). However, the gravity field (Figure 10) also reveals NW-

428 trending anomalies that have been interpreted with the aid of seismic reflection

429 and refraction data to be continental fault blocks (Cochran, 2005; Cochran and

430 Karner, 2007). In the central Red Sea, the pattern of flowage appears modulated

431 by the basement topography, with greater flowage over basement valleys where

432 the evaporites are thicker and less impeded (Augustin et al., 2014; Augustin et

433 al., 2016; Feldens and Mitchell, 2015; Mitchell et al., 2010a; Mitchell et al., 2017).

434 Whether basement topography modulates flowage also in the northern

435 Red Sea is less clear. In that case, we might expect cross-sea features such as the

436 accommodation zone marked in Figure 10 to be a zone of preferential

437 movement. Perhaps the evaporite folds interpreted immediately east of eff10

438 could represent the convergence zone. However, we don't see obvious drag folds

439 or Riedel-type shears that would help to identify differential movement.

440 Nevertheless, some of our interpreted evaporite flow fronts suggest movement

441 from areas of high free-air gravity (implying elevated basement) to low anomaly,

442 such as eff7, eff9, eff10 and eff11, perhaps indicating some movements down

443 gradients created by differential compaction of underlying sediments. In

444 contrast with the central and southern Red Sea, the abundance of linear features

445 and few rounded features suggests the importance of salt walls and hence

446 vertical tectonics, rather than horizontal movements. 
449 The sonar swath ran immediately east of Mabahiss Mons seamount, the data in

450 Figure 6 revealing an area of high backscattering most likely due to outcropping

451 volcanic rock at least $10 \mathrm{~km}$ across. Comparing the apparent geomorphology in

452 the GLORIA data with the multibeam bathymetry map of Guennoc (1990) the

453 Discovery survey line ran over the boundary between Mabahiss West and East

454 basins, which are both sediment-filled. One or more further sediment-filled

455 basins run under the track to the SE. Curiously, narrow bands of low backscatter

456 occur at the base of slope to the SE, which are either depressions filled with

457 exceptionally low backscattering sediment. The seabed immediately to the NW

458 of Mabahiss Mons also appears to comprise generally low backscattering

459 sediment.

$460 \quad$ A higher resolution view is provided by the multibeam data in Figure 8.

461 The structures here have been described by Metz (2013), who interpreted the

462 lobate morphologies of the slopes, such as the southern slope of the West Basin,

463 as due to evaporite flowage. He noted also that the patterns of lineaments on the

464 sedimentary areas are similar to those of evaporite flows interpreted further

465 south (Augustin et al., 2014; Augustin et al., 2016; Feldens and Mitchell, 2015;

466 Mitchell et al., 2010a). Although the GLORIA data have lower resolution, many

467 features can be associated with those of Figure 8, for example, a somewhat

468 rounded backscatter E-W lineament immediately south of Mabahiss West Basin.

469 The embayment of the NE slope of East Basin is observed in the GLORIA imagery,

470 as well as the gullied slope of the steep escarpment marked F in Figure 6. Metz

471 (2013) suggested that Mahahiss Mons probably blocks flowage into the Mabahiss

472 West Basin from the north. The lack of halokinetic structures immediately NW of 
473 Mahabiss Mons (south of "Evaporite Folds" marked on Figure 6) would be 474 compatible with that idea.

Structures associated with the Zabargad Fracture Zone

477 A major tectonic structure running NNE immediately north of Zabargad Island is 478 the Zabargad Fracture Zone (FZ), marked by an elongate free-air gravity low 479 (Figure 10). The fracture zone is less clear in bathymetry maps, but a step or 480 depression of $\sim 100-200 \mathrm{~m}$ is commonly revealed in traversing ship tracks. This 481 feature likely accommodates differential plate motion between the laterally 482 offset extensional regions of Vema Deep and Gypsum Deep. The westerly major 483 lineament marked "F" also is oriented NNE. However, this fault and another two 484 minor faults within the fracture zone valley (Figure 5) lie counter-clockwise of 485 the Arabia-Nubia motion direction of the last few million years according to Chu 486 and Gordon (1998) (red lines in Figures 9 and 10), suggesting that motion across 487 the fracture zone may be transtensional. The presence of rounded features with 488 corrugations suggests flowage into the fracture zone valley (Figures 5). Such 489 flowage implies that the floor of the fracture zone has subsided relative to 490 adjacent basement blocks since the end of the Miocene termination of the 491 evaporite phase, also compatible with transtensional deformation across the 492 fracture zone.

$494 \quad$ Conclusions

495 The GLORIA images reveal lineaments (folds and faults) with a wide range of 496 orientations in the northern Red Sea. Many linear features are likely to 497 represent the surface expressions of salt walls. Interestingly some linear 
features are oriented parallel with an accommodation zone revealed by the free-

499 air gravity field. In the centre of that zone, the GLORIA data suggest a set of folds

500 occurs, which may represent a zone of evaporite convergence. Elsewhere, the

501 data show rounded corrugated features that may be flow fronts, many of which

502 run from areas of free-air gravity highs to lows. Nevertheless, vertical tectonics

503 (in the form of salt walls) appears to be emphasized over horizontal tectonics in

504 the northern Red Sea, in contrast with the central Red Sea, where structures

505 indicating horizontal movement dominate. The generally more subdued seabed

506 gradients in the northern Red Sea, where the deeps are less well developed, may

507 explain this difference. More generally, we predict that the style of early

508 halokinetic deformation originally occurring at more mature margins such as

509 around the Atlantic may crucially have depended on the original seabed and

510 evaporite surface gradients, unfortunately parameters that are poorly known.

511 Rounded corrugated structures in the Zabargad Fracture Zone suggest

512 flowage into the fracture zone depression. We suggest that this is caused by

513 subsidence along the fracture zone and would be compatible with a change to

514 transtensional deformation associated with a more recent change in plate

515 motion. These and other structures revealed by the GLORIA images suggest

516 excellent targets for surveys with more modern multibeam and sidescan sonars.

518 Acknowledgements

519 The engineers and scientists involved in the GLORIA programme and in 520 particular those who served on RRS Discovery 103 are thanked for their work in

521 collecting these data, which was funded by the UK Natural Environment

522 Research Council. Lisa Marsh of the National Oceanographic Centre 
523 (Southampton, UK) is thanked for lending us the GLORIA prints for scanning. For

524 raw bathymetric data collected during the MEROU78 cruise included in Figure 8, we

525 thank IFREMER. No warranty is granted by IFREMER for any use of these results

526 and all rights are reserved. Figures were produced with the aid of the GMT

527 software package (Wessel and Smith, 1991). We finally thank two anonymous

528 reviewers for comments that led to a significant improvement of this article.

$530 \quad$ References

531 Almogi-Labin, A., Hemleben, C., Meischner, D., 1998. Carbonate preservation and

532 climate changes in the central Red Sea during the last $380 \mathrm{kyr}$ as recorded by

533 pteropods. Mar. Micropal. 33, 87-107.

534 Augustin, N., Devey, C.W., van der Zwan, F.M., Feldens, P., Tominaga, M., Bantan,

535 R., Kwasnitschka, T., 2014. The transition from rifting to spreading in the Red Sea.

536 Earth Planet. Sci. Lett. 395, 217-230.

537 Augustin, N., van der Zwan, F.M., Devey, C.W., Ligi, M., Kwasnitschka, T., Feldens,

538 P., Bantan, R., Basaham, A.S., 2016. Geomorphology of the central Red Sea Rift:

539 Determining spreading processes. Geomorph. 274, 162-179.

540 Becker, J.J., Sandwell, D.T., Smith, W.H.F., Braud, J., Binder, B., Depner, J., Fabre,

541 D., Factor, J., Ingalls, S., Kim, S.-H., Ladner, R., Marks, K., Nelson, S., Pharaoh,

542 A., Trimmer, R., Von Rosenberg, J., Wallace, G., Weatherall, P., 2009. Global

543 Bathymetry and Elevation Data at 30 Arc Seconds Resolution: SRTM30_PLUS.

$544 \quad$ Marine Geodesy 32, 355-371.

545 Bicknell, J.D., Macdonald, K.C., Miller, S.P., Longsdale, P.F., Becker, K., 1986.

546 Tectonics of the Nereus Deep, Red Sea: A deep tow investigation of a site of

547 initial rifting. Mar. Geophys. Res. 8, 131-148. 
548 Blondel, P., Murton, B.J., 1997. Interpretation of sidescan sonar imagery. John Wiley, 549 Chichester.

550 Bonatti, E., Ball, M., Schubert, C., 1970. Evaporites and continental drift.

$551 \quad$ Naturwissenschaften 57, 107-108.

552 Bonatti, E., Colantoni, P., Della Vedova, B., Taviani, M., 1984. Geology of the Red 553 Sea transitional zone $\left(22^{\circ} \mathrm{N}-25^{\circ} \mathrm{N}\right)$. Oceanologica Acta $7,385-398$.

554 Chu, D., Gordon, R.G., 1998. Current plate motions across the Red Sea. Geophys. J. $555 \quad$ Int. $135,313-328$.

556 Clay, C.S., Medwin, H., 1977. Acoustical oceanography: principles and applications.

557 Wiley Interscience, New York.

558 Cochran, J.R., 1983. A model for the development of the Red Sea. Am. Assoc. Petrol. Geol. $559 \quad$ Bull. 67, 41-69.

560 Cochran, J., Martinez, F., Steckler, M.S., Hobart, M.A., 1986. Conrad Deep: A 561 northern Red Sea deep. Origin and implication for continental rifting. Earth $562 \quad$ Planet. Sci. Lett. 78, 18-32.

563 Cochran, J.R., 2005. Northern Red Sea: Nucleation of an oceanic spreading center 564 within a continental rift. Geochemistry, Geophysics, Geosystems 6, Paper Q03006, 565 doi:03010.01029/02004GC000826.

566 Cochran, J.R., Karner, G.D., 2007. Constraints on the deformation and rupturing of 567 continental lithosphere of the Red Sea: the transition from rifting to drifting, in: 568 Karner, G.D., Manatschal, G., Pinheiro, L.M. (Eds.), Imaging, mapping and 569 modelling continental lithosphere extension and breakup, Spec. Publ. 282.

$570 \quad$ Geological Society, London, London, pp. 265 - 289.

571 Coutelle, A., Pautot, G., Guennoc, P., 1991. The structural setting of the Red Sea axial 572 valley and deeps: implications for crustal thinning processes. Tectonophys. 198, 
395-409.

574 Dyment, J., Tapponnier, P., Afifi, A.M., Zinger, M.A., Franken, D., Muzaiyen, E., 2013. A new seafloor spreading model of the Red Sea: magnetic anomalies and plate kinematics, American Geophysical Union, Fall Meeting, abstract \#T21A-2512.

Egloff, F., Rihm, R., Makris, J., Izzeldin, Y.A., Bobsien, M., Meier, K., Junge, P., Noman, T., Warsi, W., 1991. Contrasting structural styles of the eastern and western margins of the southern Red Sea: the 1988 SONNE experiment. Tectonophys. 198, 329-353.

Ehrhardt, A., Hübscher, C., 2015. The northern Red Sea in transition from rifting to drifting - lessons learned from ocean deeps, in: Rasul, N., Stewart, I.C. (Eds.), The Red Sea: The formation, morphology, oceanography and environment of a young ocean basin. Springer, pp. 99-121.

584 Ehrhardt, A., Hübscher, C., Gajewski, D., 2005. Conrad Deep, Northern Red Sea:

585 Development of an early stage ocean deep within the axial depression.

586 Tectonophys. 411, 19-40.

587 Feldens, P., Mitchell, N.C., 2015. Salt flows in the central Red Sea, in: Rasul, N., 588 Stewart, I.C. (Eds.), The Red Sea: The formation, morphology, oceanography and 589 environment of a young ocean basin. Springer, pp. 205-218.

590 Garfunkel, Z., Ginzburg, A., Searle, R.C., 1987. Fault pattern and mechanism of 591 crustal separation along the axis of the Red Sea from side scan sonar (GLORIA) 592 data. Annales Geophysicae 5B, 187-200.

593 Girdler, R.W., Whitmarsh, R.B., 1974. Miocene evaporites in Red Sea cores, their 594 relevance to the problem of the width and age of oceanic crust beneath the Red 595 Sea, in: Whitmarsh, R.B., Weser, O.E., Ross, D.A., et al. (Eds.), Initial Reports of 596 the Deep Sea Drilling Project, Vol. 23. U.S. Govt. Printing Office, Washington, D.C., pp. 913-921. 
598 Gordon, G., Hansen, B., Scott, J., Hirst, C., Graham, R., Grow, T., Spedding, A., Fairhead, S., Fullarton, L., Griffin, D., 2010. The hydrocarbon prospectivity of the Egyptian North Red Sea basin, in: Vining, B.A., Pickering, S.C. (Eds.), Petroleum geology: from mature basins to new frontiers - Proceedings of the 7th Petroleum Geology Conference. Geol. Soc. Lond., pp. 783-789.

604 Sea axial valley from $23^{\circ} \mathrm{N}$ to $28^{\circ} \mathrm{N}$ : time and space evolution of neo-oceanic 605 structures. Tectonophys. 153, 1-23.

606 Guennoc, P., Pautot, G., LeQentrec, M.-F., Coutelle, A., 1990. Structure of an early 607 oceanic rift in the northern Red Sea. Oceanologica Acta 13, 145-157.

608 Izzeldin, A.Y., 1987. Seismic, gravity and magnetic surveys in the central part of the Red 609 Sea: their interpretation and implications for the structure and evolution of the Red $610 \quad$ Sea. Tectonophysics 143, 269-306.

611 LaBrecque, J.L., Zitellini, N., 1985. Continuous seafloor spreading in the Red Sea: An 612 alternative interpretation of the magnetic anomaly pattern. A.A.P.G. Bull. 69, 513613524.

614 Levi, S., Riddihough, R., 1986. Why are marine magnetic anomalies suppressed over 615 sedimented spreading centres? Geology 14, 651-654.

616 Ligi, M., Bonatti, E., Bortoluzzi, G., Cipriani, A., Cocchi, L., Caratori Tontini, F., 617 Carminati, E., Ottolini, L., Schettino, A., 2012. Birth of an ocean in the Red Sea: 618 Initial pangs. Geochem. Geophys. Geosys. 13, Paper Q08009, 619 doi:08010.01029/02012GC004155.

620 Ligi, M., Bonatti, E., Tontini, F.C., Cipriani, A., Cocchi, L., Schettino, A., Bortoluzzi, 621 G., Ferrante, V., Khalil, S., Mitchell, N.C., Rasul, N., 2011. Initial burst of oceanic 622 crust accretion in the Red Sea due to edge-driven mantle convection. Geology 39, 
1019-1022.

624 Mart, Y., Rabinowitz, P.D., 1986. The Northern Red Sea and the Dead Sea Rift.

$625 \quad$ Tectonophysics $124,85-113$

626 Mart, Y., Ross, D.A., 1987. Post-Miocene rifting and diapirism in the northern Red 627 Sea. Mar. Geol. 74, 173-190.

628 Martinez, F., Cochran, J.R., 1988. Structure and tectonics in the northern Red Sea:

629 catching a continental margin between rifting and drifting. Tectonophys. 150, 1-32.

630 Martinez, F., Cochran, J.R., 1989. Geothermal Measurements in the northern Red

631 Sea: Implications for lithospheric thermal structure and mode of extension during

632 continental rifting. J. Geophys. Res. 94, 12,239-212,266.

633 Metz, D., 2013. Mabahiss Mons, 25.5 N Red Sea Rift: tectonics and volcanism of a

634 large submarine dome volcano, Faculty of Mathematics and Natural Science. MSc

635 dissertation, Christian-Albrechts University of Kiel, Kiel, Germany, p. 60.

636 Milliman, J.D., Ross, D.A., Ku, T.-L., 1969. Precipitation and lithification of deep-sea 637 carbonates in the Red Sea. J. Sed. Petrol. 39, 724-736.

638 Mitchell, N.C., 1991. Improving GLORIA images using Sea Beam data. J. Geophys. 639 Res. 96, 337-351.

640 Mitchell, N.C., 1993. A model for attenuation of backscatter due to sediment 641 accumulations and its application to determine sediment thickness with GLORIA 642 sidescan sonar. J. Geophys. Res. 98, 22477-22493.

643 Mitchell, N.C., Ligi, M., Farrante, V., Bonatti, E., Rutter, E., 2010a. Submarine salt 644 flows in the central Red Sea. Geol. Soc. Am. Bull. 122, 701-713.

645 Mitchell, N.C., Ligi, M., Feldens, P., Hübscher, C., 2017. Deformation of a young salt 646 giant: regional topography of the Red Sea Miocene evaporites. Basin Res, 29, 352647 369. 
648 Mitchell, N.C., Ligi, M., Rohling, E.J., 2015. Red Sea isolation history suggested by

649 Plio-Pleistocene seismic reflection sequences. Earth Planet. Sci. Lett. 430, 387650397.

651 Mitchell, N.C., Park, Y., 2014. Nature of crust in the central Red Sea. Tectonophys. $652628,123-139$.

653 Mitchell, N.C., Schmidt, M., Ligi, M., 2010b. Comment on "Formation of Thetis 654 Deep metal-rich sediments in the absence of brines, Red Sea" by Pierret et al. 655 (2010). J. Geochem. Expl. 108, 112-113.

656 Mitchell, N.C., Somers, M.L., 1989. Quantitative backscatter measurements with a 657 long range side-scan sonar. IEEE J. Oceanic Eng. 14, 368-374.

658 Pautot, G., 1983. Red Sea deeps - A geomorphological study by Seabeam. Oceanol. $659 \quad$ Acta 6, 235-244.

660 Pautot, G., Auzende, J.M., LePichon, X., 1966. Continuous deep salt layer along 661 North Atlantic margins related to early phase of rifting. Nature 227, 351-354.

662 Pierret, M.C., Clauer, N., Bosch, D., Blanc, G., 2010. Formation of Thetis Deep 663 metal-rich sediments in the absence of brines, Red Sea. J. Geochem. Expl. 104, 1266426.

665 Richter, H., Makris, J., Rihm, R., 1991. Geophysical observations offshore Saudi 666 Arabia: seismic and magnetic observations. Tectonophys. 198, 297-310.

667 Rona, P.A., 1982. Evaporites at passive margins, in: Scrutton, R.A. (Ed.), Dynamics 668 of passive margins. Am. Geophys. Union and Geol. Soc. Am., Washington, DC, 669 pp. 116-132.

670 Rowan, M.G., 2014. Passive-margin salt basins: hyperextension, evaporite deposition, 671 and salt tectonics. Basin Res. 26, 154-182.

672 Rusby, J.S.M., Dobson, R., Edge, R.H., Pierce, F.E., Somers, M.L., 1969. Records obtained 

from the trials of a long range side-scan sonar (GLORIA Project). Nature 223, 125-126.

674 Rusby, J.S.M., 1970. A long range side-scan sonar for use in the deep sea. International 675 Hydrographic Review 47, 25-39.

676 Sandwell, D., Müller, R.D., Smith, W.H.F., Garcia, E., Francis, R., 2014. New global 677 marine gravity model from CryoSat-2 and Jason-1 reveals buried tectonic 678 structure. Science 346, 65-67.

679 Searle, R.C., 1980. R.R.S. Discovery Cruise 103, 9-25 July 1979, Geology and 680 geophysics in the Gulf of Aden and Red Sea, Cruise Report No 88. Institute of 681 Oceanographic Sciences, UK (NERC), p. 21.

682 Searle, R.C., Ross, D.A., 1975. A geophysical study of the Red Sea axial trough 683 between $20.5^{\circ}$ and $22^{\circ}$ N. Geophys. J. Roy. Astr. Soc. 43, 555-572.

684 Searle, R.C., Le Bas, T.P., Mitchell, N.C., Somers, M.L., Parson, L.M., 1990. GLORIA 685 Image Processing: The State of the Art. Mar. Geophys. Res. 12, 21-39.

686 Somers, M.L., Carson, R.M., Revie, J.A., Edge, R.H., Barrow, B.J., Andrews, A.G., 687 1978. Gloria II - an improved long range sidescan sonar, Oceanology International, 688 Proceedings, Offshore Instrumentation and Communications. Institute of Electrical 689 Engineers, New York, London, pp. 16-24.

690 Somers, M.L., Searle, R.C., 1984. GLORIA sounds out the seabed. New Scientist $691 \quad 104,12-15$.

692 Spiers, C.J., Schutjens, P.M.T.M., Brzesowsky, R.H., Peach, C.J., Liezenberg, J.L., 693 Zwart, H.J., 1990. Experimental determination of constitutive parameters 694 governing creep of rocksalt by pressure solution, in: Knipe, R.J., Rutter, E.H. 695 (Eds.), Deformation mechanisms, rheology and tectonics, Geol. Soc. Spec. Publ. 696 54. Geol. Soc., London, pp. 215-227.

697 Tramontini, C., Davies, D., 1969. A seismic refraction survey in the Red Sea. Geophys. J. R. 
699 Wessel, P., Smith, W.H.F., 1991. Free software helps map and display data. Eos,

$700 \quad$ Transactions, American Geophysical Union 72, 441.

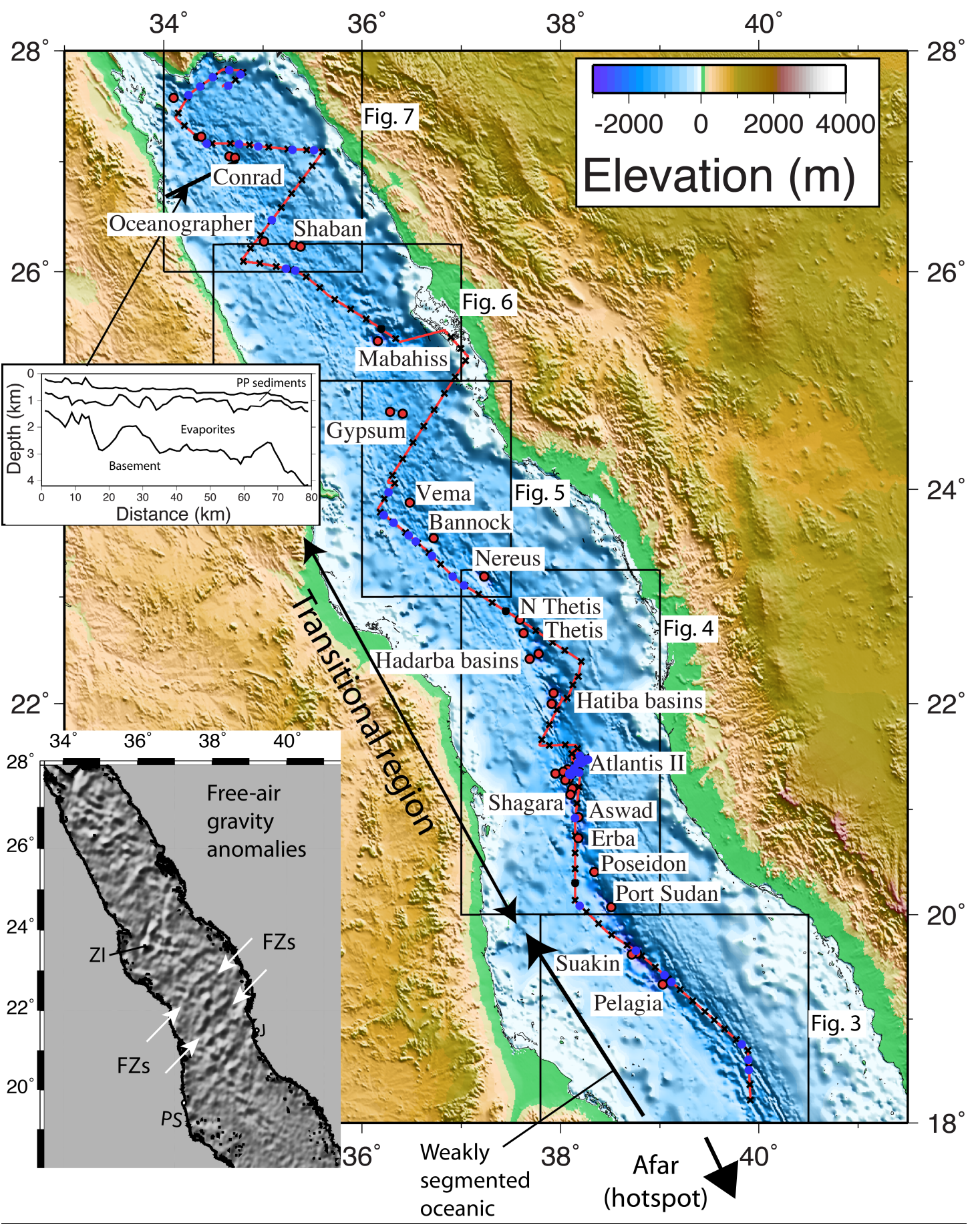


survey time. Blue solid circles represent locations of transit satellite fixes. Red

706

solid circles locate deeps compiled by Augustin et al. (2014) (only a selection of

707 their names are shown). Topography and bathymetry data are from Becker et al.

708 (2009). Inset (lower-left) shows a shaded-relief image of the satellite-derived

709 marine gravity field (Sandwell et al., 2014, their version 18.0 shaded from

710 N030 W). Further annotation: (ZI) Zabargad Island, (J) Jeddah, (PS) Port Sudan

711 and (FZs) fracture zones. Second inset (upper left) is crustal cross-section near

712 Conrad Deep interpreted by Martinez and Cochran (1989) from industry

713 multichannel seismic reflection data.

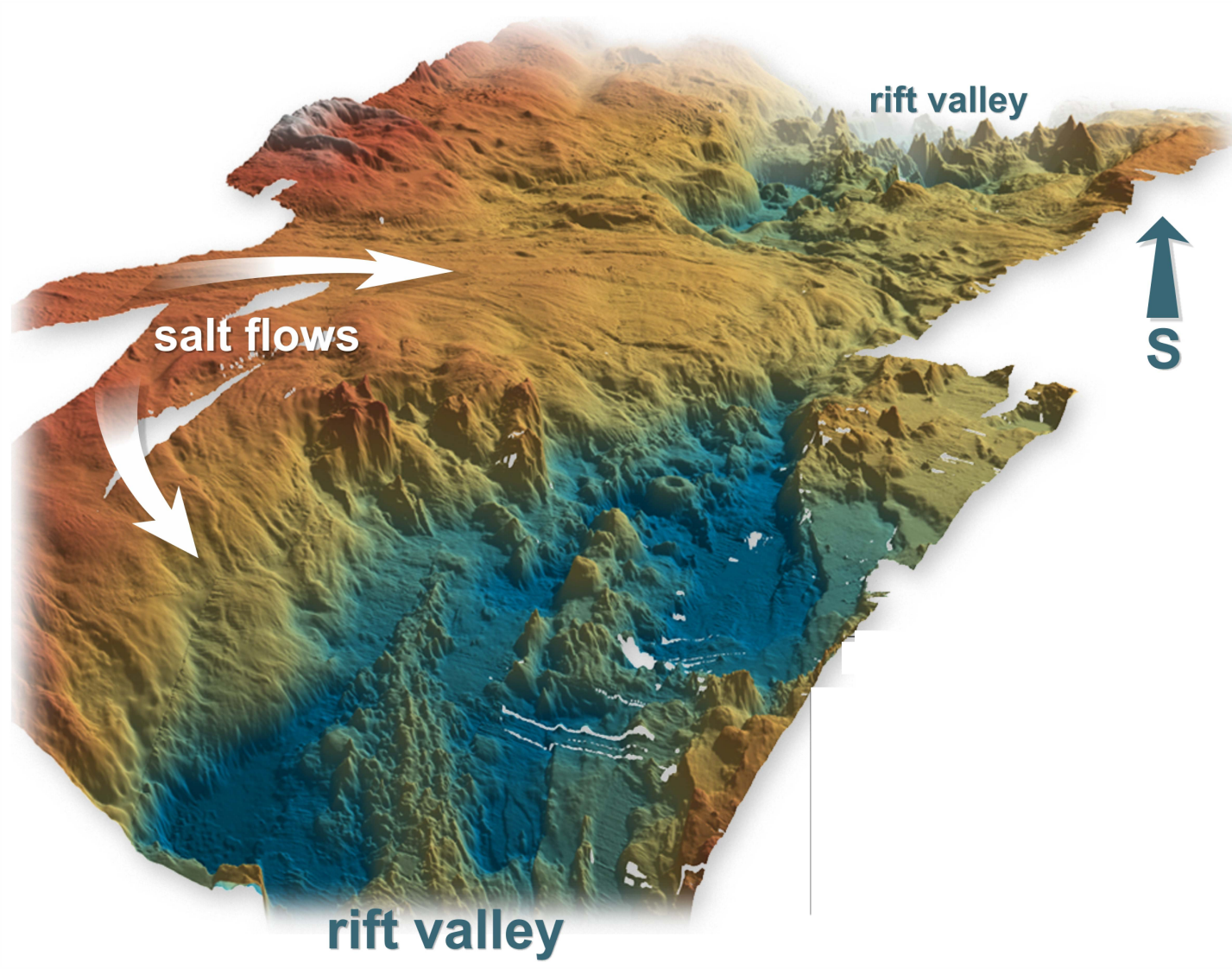

715 Figure 2. 3D view of multibeam data showing salt flows invading the axial rift

716 valley, with Erba and Aswan deeps in the foreground (Augustin, 2014). Width of

717 data in view is $\sim 30 \mathrm{~km}$. Depths in field of view vary from $800 \mathrm{~m}$ (white) to 2400

718 m (blue). 


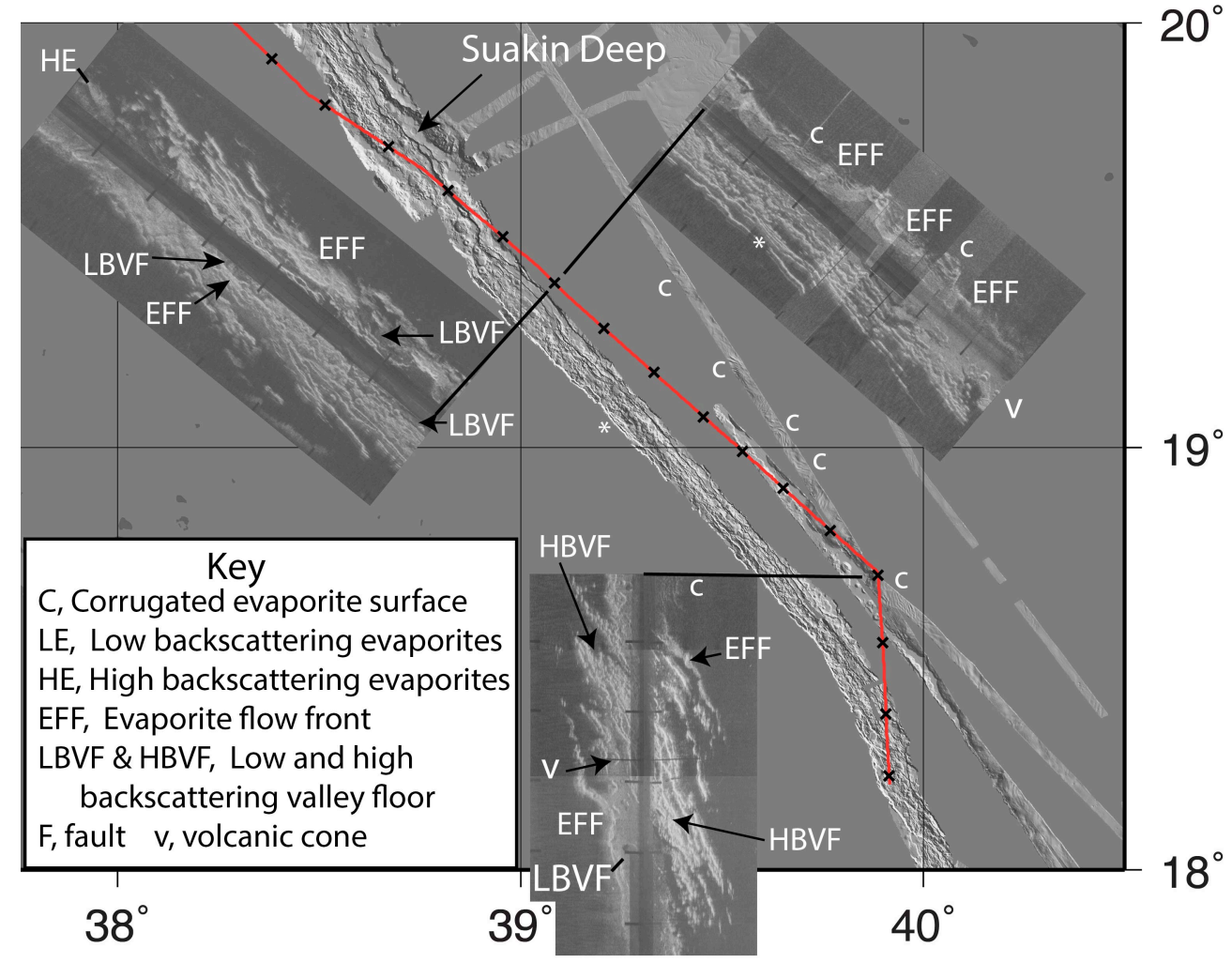

720 Figure 3. GLORIA image panels shown alongside a shaded relief image of the

721 multibeam bathymetry (Augustin et al., 2014; Augustin et al., 2016) (artificial

722 sun from $\mathrm{N} 060^{\circ} \mathrm{E}$ ). GLORIA photographic prints have been scaled and oriented

723 to the hourly marks along the Discovery trackline but are shown offset from the

724 track to allow features to be compared with the multibeam data (black lines

725 associate hour marks). 


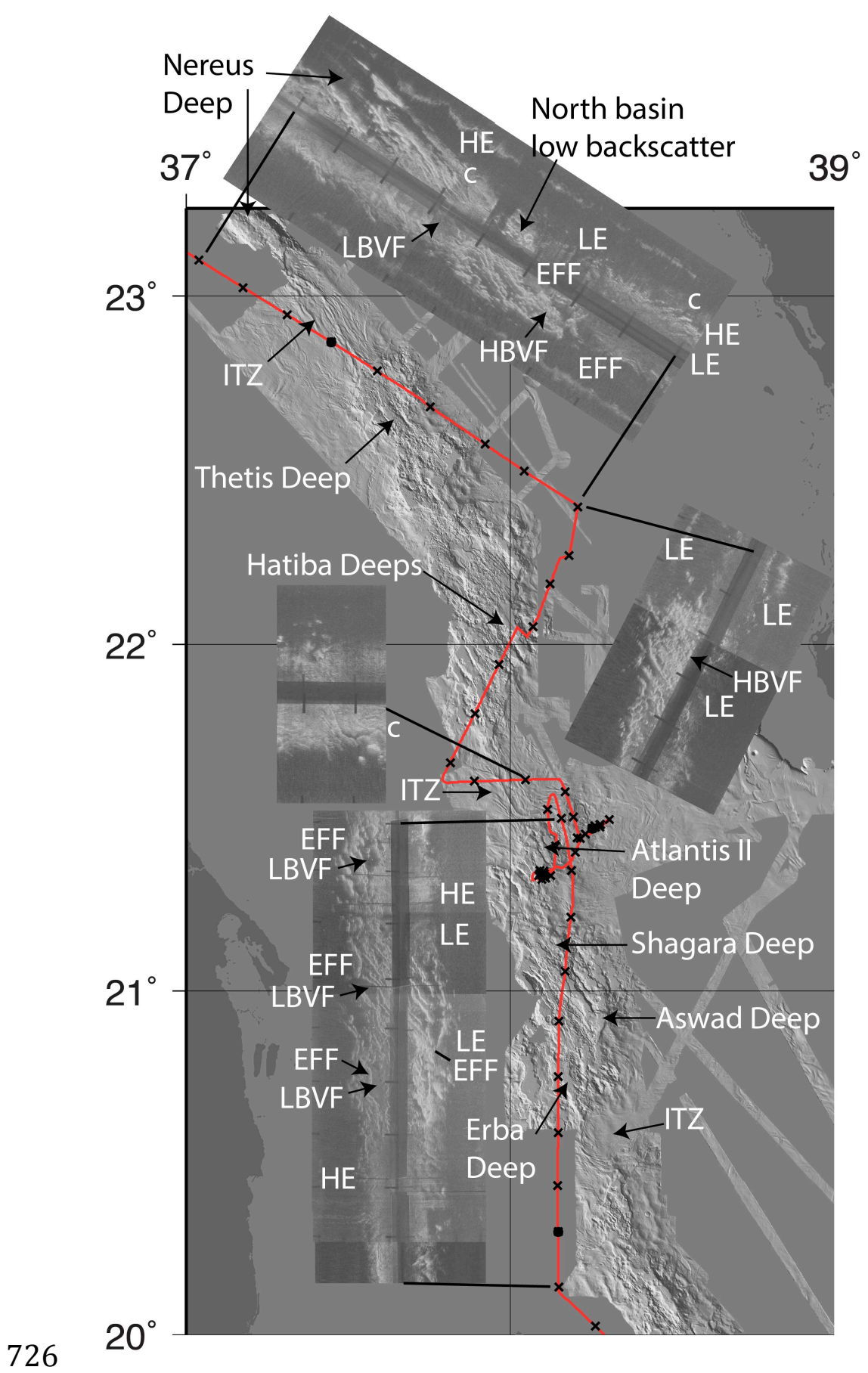

727 Figure 4. GLORIA image panels shown alongside a shaded relief map of the

728 multibeam bathymetry, as Figure 3. Annotation ITZ: inter-trough zone (other 729 annotation as Figure 3). 


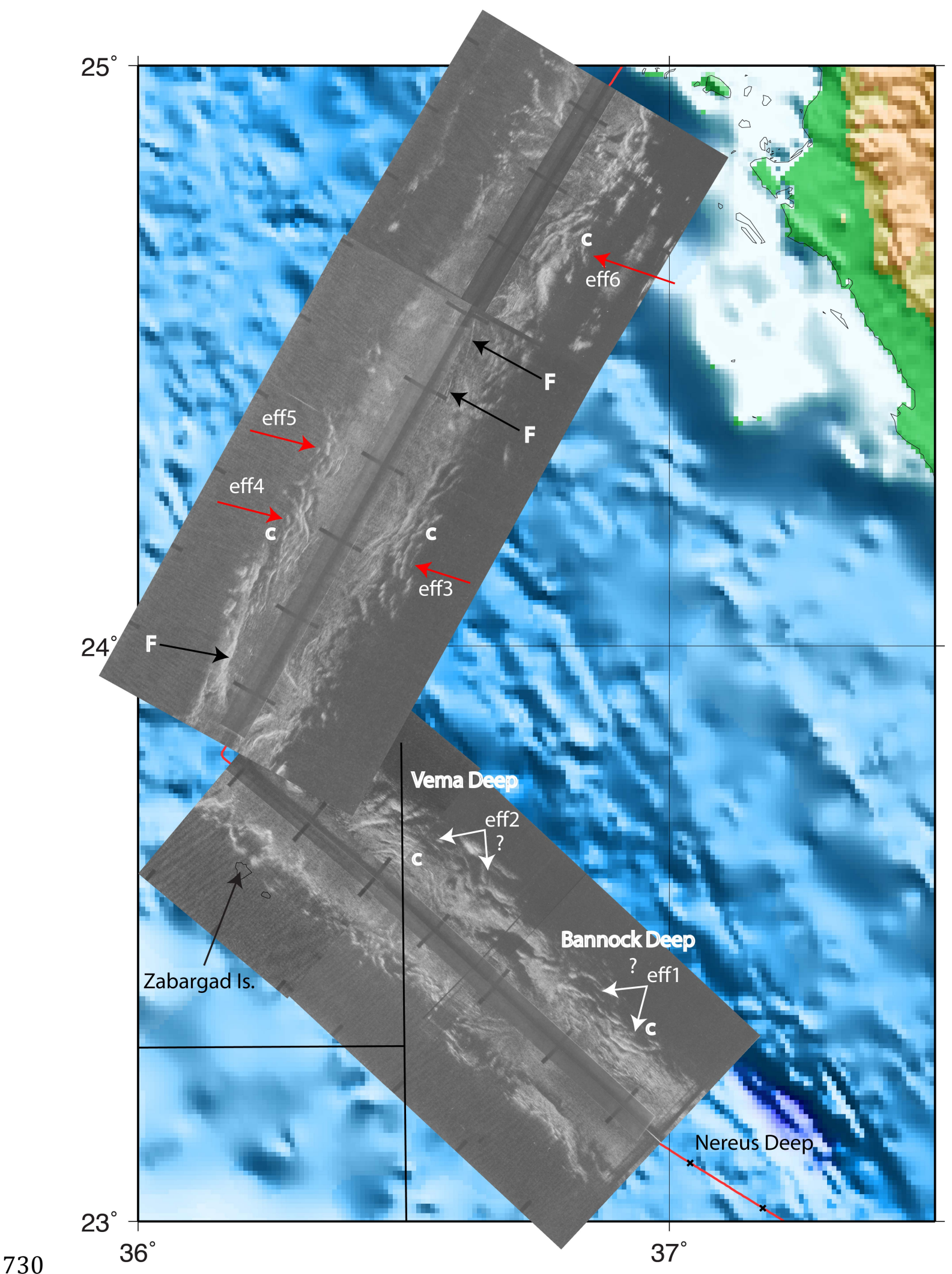

731 Figure 5. Gloria image panels oriented along Discovery track in the central Red

732 Sea, with the topographic and bathymetry data of Becker et al. (2009) as

733 background (colour scale as Figure 1). Arrows mark possible flowage directions. 


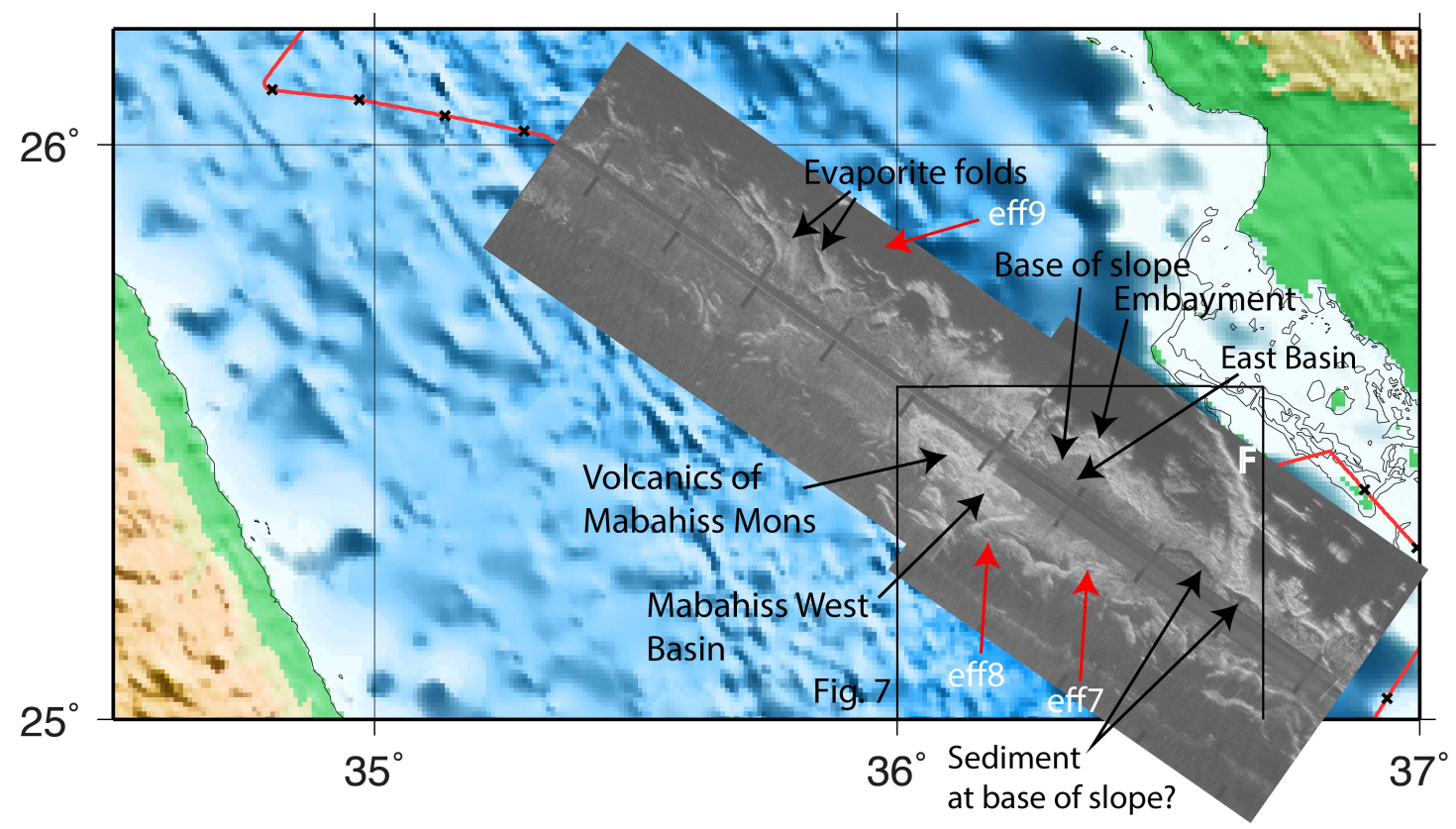

Figure 6. GLORIA image passing over Mabahiss Deep, as Figure 5. 


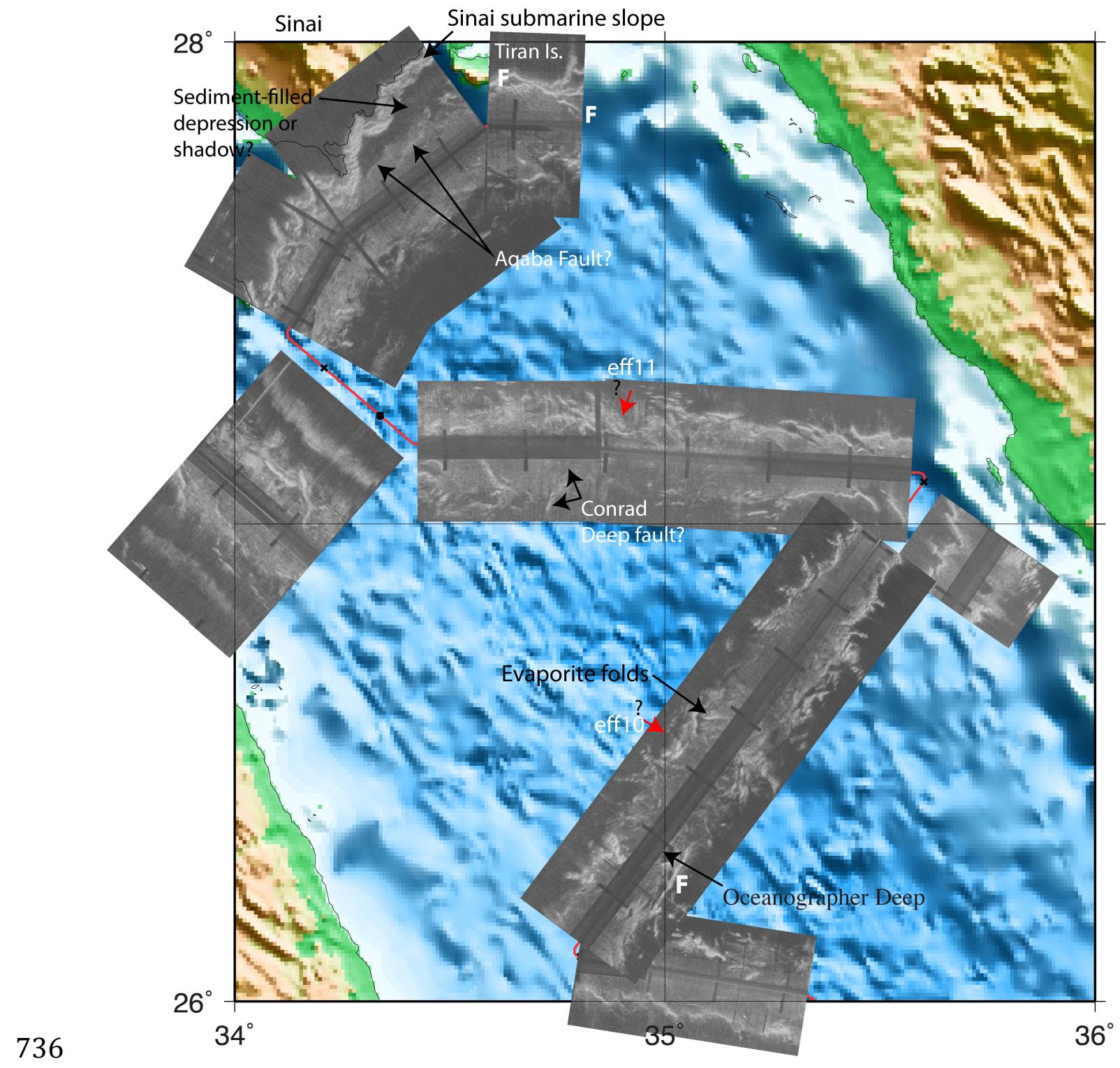

737 Figure 7. GLORIA images in the northern Red Sea, as Figure 5. 


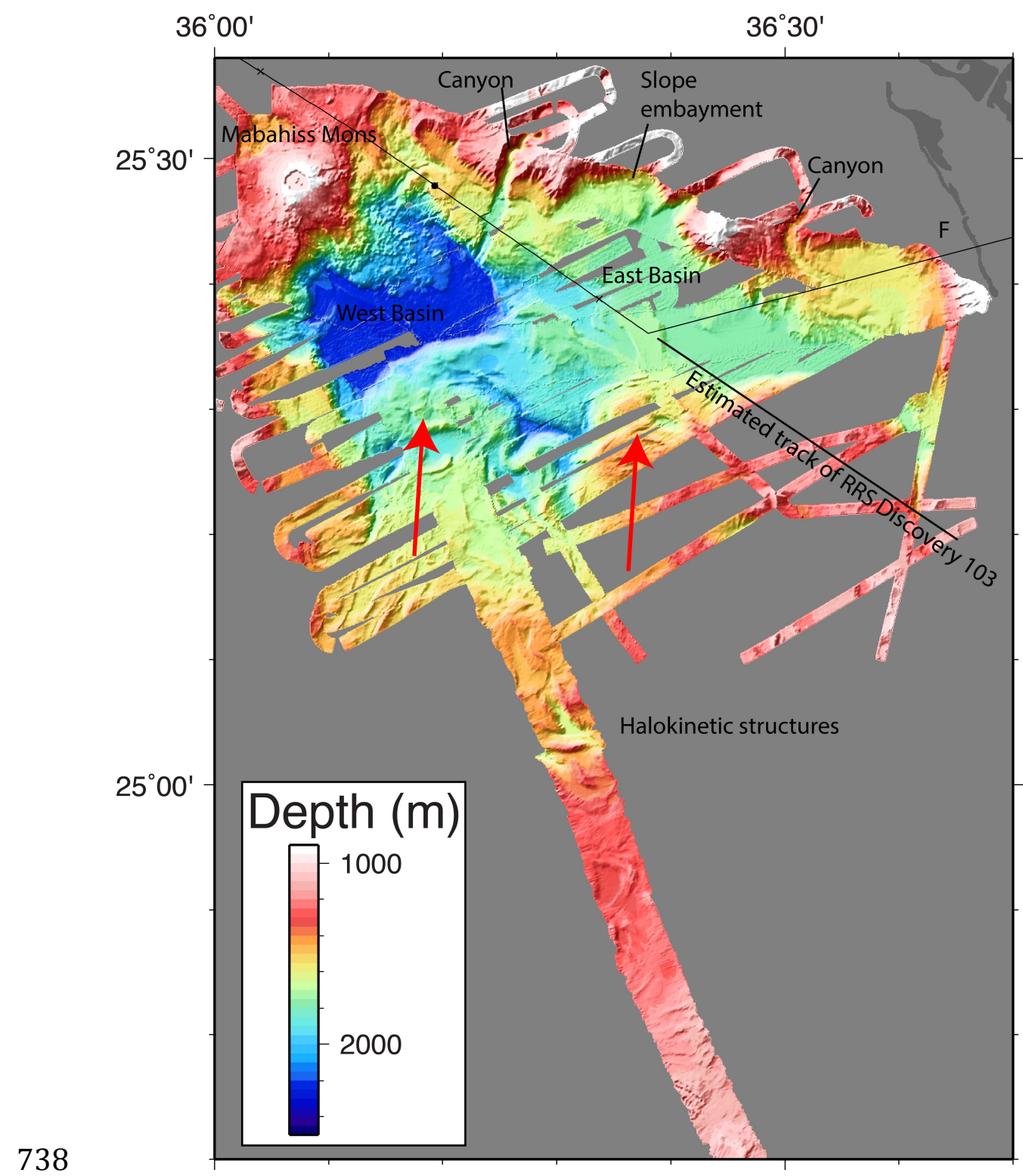

739 Figure 8. Bathymetry of Mabahiss Mons seamount and adjacent deeps.

740 Multibeam data include RV Pelagia data from the compilation of Augustin et al.

741 (2016), supplemented with data from Guennoc et al. (1988; 1990). Where the

742 sounding data from the two sets of surveys overlap, preference was given to the

743 Augustin et al. (2016) data. The Guennoc et al. (1988; 1990) data were collected

744 on RV Jean Charcot with a 16-beam multibeam sonar (narrower swaths in the

745 figure). Artificial illumination is from N045 W. Fine line is the track of RRS

746 Discovery cruise 103 lodged with the NGDC and bold line is the presumed true

747 track. 


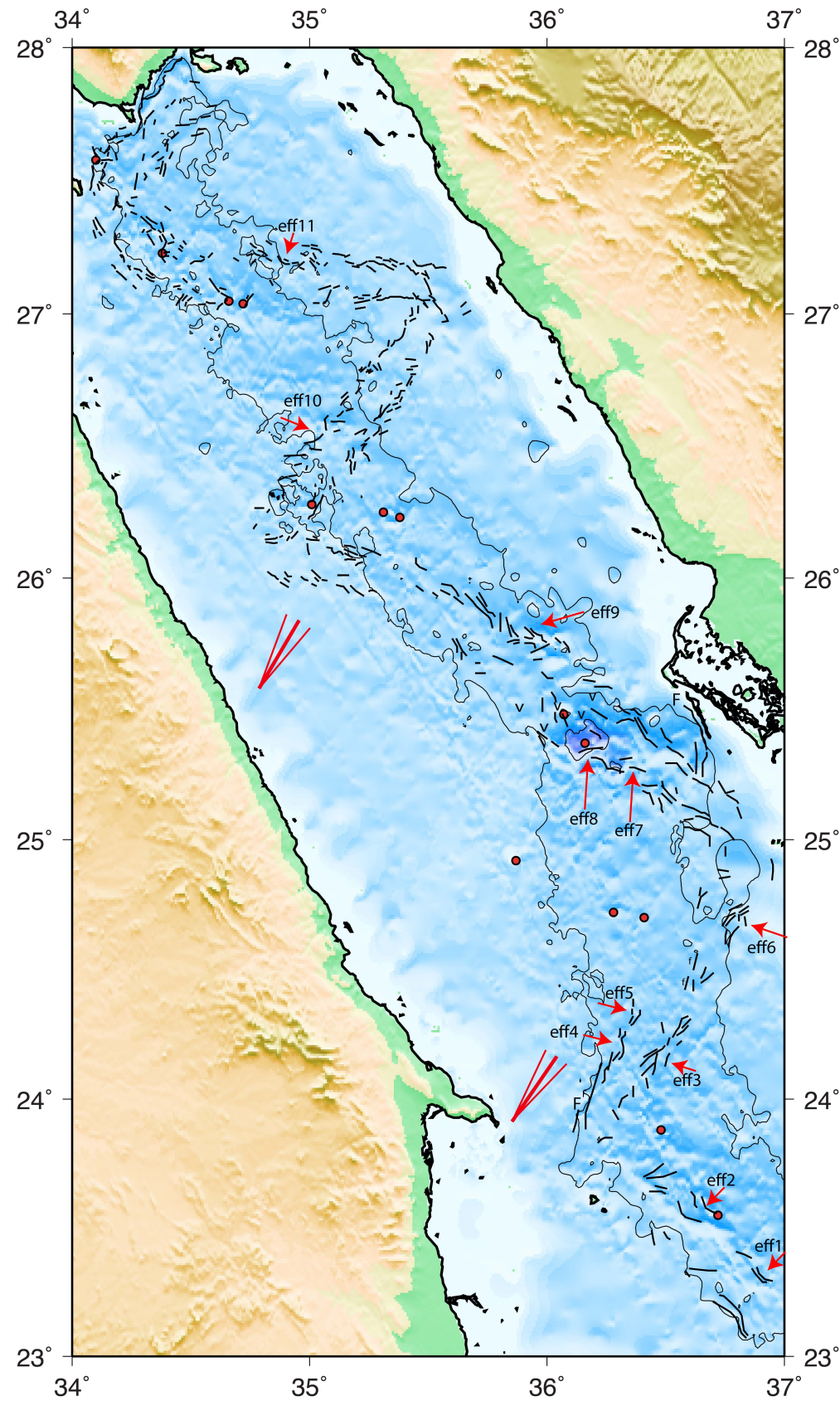

749 Figure 9. Lineaments and other backscatter boundaries interpreted from the

750 GLORIA overlain on the bathymetry (colours as Figure 1, though with intensities

751 reduced). The $1000 \mathrm{~m}$ depth contour is shown. Red filled circles are the deeps,

752 as Figure 1. Arrows indicate suggested evaporite flowage directions. Red bold

753 lines show the Nubia-Arabia plate motion directions at $24^{\circ}$ and $25.7^{\circ} \mathrm{N}$ from Chu

754 and Gordon (1998) and finer red lines show their computed 95\% confidence

755 intervals. 


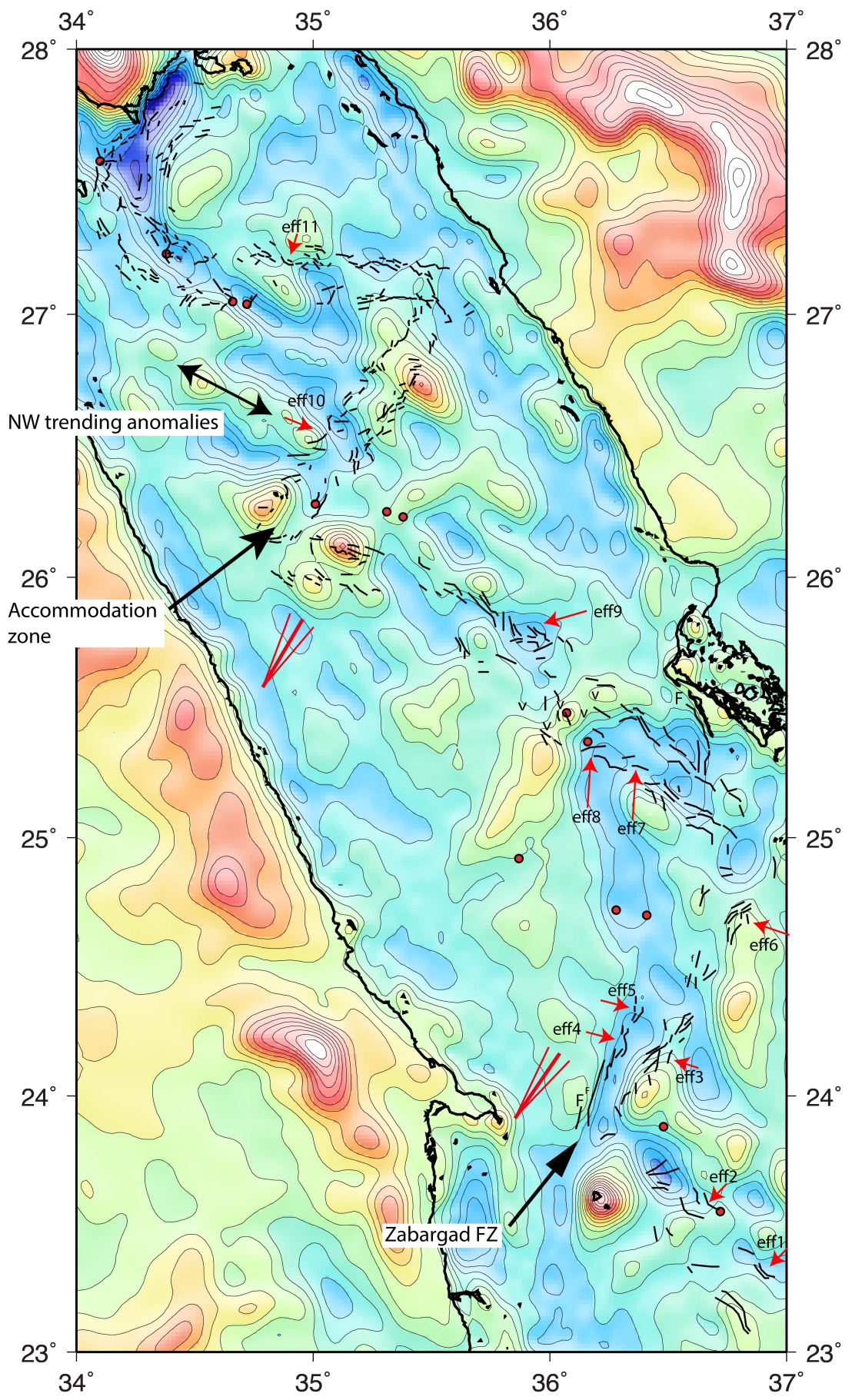

757 Figure 10. As Figure 9, with the free-air gravity field as the background

758 (Sandwell et al., 2014). Gravity anomalies are contoured every 10 mGal (0 mGal

759 level annotated); cold colours (blue) represent low values and warm colours

760 (red) represent high values). Heavy arrows are used to mark features. 


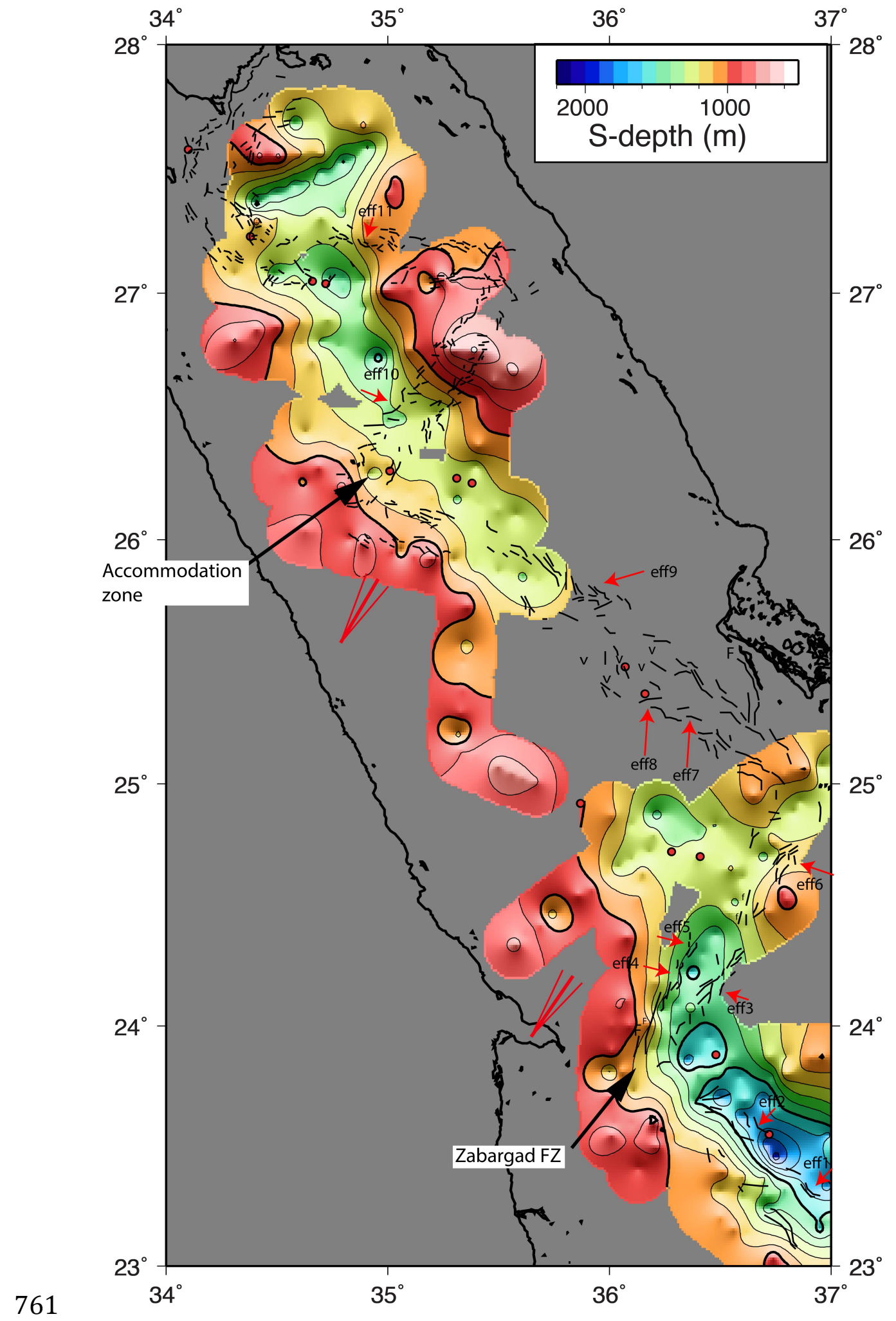

762 Figure 11. As Figure 9, with depths to the S reflection (top of the Miocene

763 evaporites) from Mitchell et al. (2017) as background. 